Yeats found the quality of exuberance in the figure of Walt Whitman, that most exuberant of poets, and I am fortunate in being able to illustrate my thesis with his sketch of a modern, secular St. Francis, whose poetry he has been reading as a pillow book, playing with the birds." 7

Hofstra University

JOANN P. KRIEG

\title{
NOTES
}

1 Letters to W. B. Yeats, ed. Richard J. Finneran, George Mills Harper, and William M. Murphy (New York: Columbia University Press, 1977), 1:96, 267.

2 The best source on Quinn is B. L. Reid, The Man from New York: fohn Quinn and His Friends (New York: Oxford University Press, 1968).

3 Finneran et al., 1:330.

4 Finneran et al., 1:312.

5 Yeats to Quinn, May 5, 1914; quoted in Finneran et al., 1:312.

6 Finneran et al., 1:427.

7 "Sketches from Letters by Jack B. Yeats," The Irish Times (August 24, 1960), 8.

\section{THE FIRST PUBLICATION OF GRACE ELLERY CHANNING'S TRIBUTE TO WHITMAN}

As Joann P. Krieg has recently noted, Grace Ellery Channing's “connections to the world of nineteenth-century literature and to Whitman" merit more attention than they have hitherto received. ${ }^{1}$ The granddaughter of William Ellery Channing, the niece of William Douglas O'Connor, as well as a close friend of and occasional collaborator with Charlotte Perkins Stetson (Gilman), Channing earned a modest reputation as a poet in her own right. She is perhaps best known today, however, as Charlotte Perkins Gilman's "co-mother" after she married the artist Charles Walter Stetson, Gilman's former husband, in 1894. Though O'Connor had offered Charlotte a copy of Leaves of Grass as early as 1883 , she had been "obliged to decline" the gift because she "had promised Walter I would not read it." "I did not want her to think all men such animals as Whitman described them," as Stetson noted in his diary. ${ }^{3}$

Ironically, as the poem reprinted below suggests, Grace Channing, Stetson's second wife, championed the genius of Whitman, her uncle's friend. Channing apparently persuaded Charlotte to read Whitman after she ended her marriage to Stetson in 1890 and moved to Pasadena to live near the Channings. In any event, Charlotte soon began to quote such verses as "Beginners" and "Song of Myself" in her lectures, and as early as February 1891 she hailed Whitman as "America's greatest poet." Near the end of her life, in fact, Charlotte publicly declared that Whitman had been one of "our two greatest Americans."

The first publication of Channing's poem "Walt Whitman" in the Boston Transcript for September 10, 1892, narrows its date of composition to the first 
three months after Whitman's death the previous May. ${ }^{5}$ Channing expresses the hope in the tribute, which is utterly conventional in form, that the news of his death reaching her in Italy may yet prove to be false. She subsequently revised the poem slightly and collected it in her volume Sea-Drift (1899) under the title "The Voiceless Syllables of Grass."

O'er Tuscan hills I heard it breathed, And through the olive groves it ran, And then the laurel all began

Singing of brows once-laurel-wreathed;

Of bards, whose vanished voices fill The resonant, deep valleys yet.

The laurel never can forget,

Such echoes tremble through it still!

But I-I let the laurel pass,

And pass the dim, Etruscan land;

Far louder sound, with my hand,

The voiceless syllables of Grass.

Your music keeps the mighty ring,

$\mathrm{O}$ ancient grove of Tuscany!

But tenfold eloquent to me,

The common weed he taught to sing.

Green art thou, laurel, overhead, Yet somber to this tiny blade;

And someone says that he, who made

The grass and me to live, is dead!

It may be true-for Italy

Hath seen the night of many a sun;

Thou, O my country hadst but one!

Yet Dante died! — so this may be.

It may be false- the sky's as blue,

The ilex hath not dropped a leaf,

Nor Earth put off a rose, for grief,

And yet, for all-it may be true!

Unruffled, silver olives wave,

Still sings the laurel where I pass;

But I-I only hear the grass,

The grass, loud-growing on a grave.

GRACE ELLERY CHANNING.

Fiesole, Italy. 


\section{NOTES}

1 Joann P. Krieg, "Grace Ellery Channing and the Whitman Calendar," Walt Whitman Quarterly Review 12 (Winter 1995), 252-256.

2 Gary Scharnhorst, Charlotte Perkins Gilman (Boston: Twayne, 1985), 40-41.

3 Mary A. Hill, Endure: The Diaries of Charles Walter Stetson (Philadelphia: Temple University Press, 1982), 201.

4 Scharnhorst, 41, 48.

5 Grace Ellery Channing, "Walt Whitman," Boston Transcript (September 10, 1892), 14:1. This publication has not previously been noted by scholars.

6 Channing, Sea-Drift (Boston: Small, Maynard, 1899), 61-62. 